DOI 10.37882/2223-2982.2020.11.31

\title{
ПРИЧИНЫ ПОЯВЛЕНИЯ АЛЬТЕРНАТИВНЫХ ПЕЧАТНЫХ ИЗДАНИЙ НА ДОНБАССЕ В ПЕРИОД ПЕРЕСТРОЙКИ (1985-1991Г.) И ИХ ВЛИЯНИЕ НА ОБЩЕСТВЕННО ПОЛИТИЧЕСКИЕ ПРОЦЕССЫ В РЕГИОНЕ
}

\section{THE REASONS OF APPEARANCE OF ALTERNATIVE PRINT EDITIONS IN DONBASS DURING THE PERIOD OF PERESTROIKA (1985-1991) AND THEIR INFLUENCE SOCIO-POLITICAL PROCESSES IN THE REGION}

\section{A. Poklonskij}

Summary: The article is devoted to the process of evolution of mass media in Donbass during the period of perestroika (1985-1991). The general socio-political characteristics of this historical period are represented in the article. The main idea is that print editions stopped to be under the control of censorship and became to eliminate relevant events of the country. There were alternative mass media in Donbass, which were opposed to current political regime.

Keywords: perestroika, publications in mass media, glasnost, censorship, Donbass.

\author{
Поклонский Александр Олегович \\ Асnирант, Донецкий Национальный университет \\ aleksandrpoklonskij4@gmail.com
}

Аннотация: Настоящая статья посвящена эволюции СМИ на Донбассе в период перестройки (1985-1991). В статье представлены общие социально-политические характеристики данного исторического периода. Основная мысль сводится к тому, что печатные издания вышли из-под контроля цензуры и стали критически освещать происходящие в стране события. На Донбассе стали появляться альтернативные издания, которые оппозиционно относились к существующему режиму.

Ключевые слова: перестройка, печатные издания, гласность, цензура, Донбасc.

Объективно перестройка стала полем пересечения трех сил. С одной стороны, были сторонники демократизации социализма. Их можно назвать сторонниками перестройки. Сюда входили представители интеллектуальной части партийного аппарата ЦК КПСС, представители обкомов партии и ЦК национальных республик. Также в круги приверженцев перестройки входили преподаватели вузов, научные сотрудники-обществоведы, сотрудники научно-исследовательских институтов. Представителями второй силы стали многие работники партийного аппарата в горкомах, обкомах, райкомах партии. Третья группа выступала против преобразований перестройки. По их мнению, все предложенные изменения были медлительными и непродуктивными.

Таким образом, период перестройки - это не только экономический и политический крах советской системы, но и противоборство политических сил, появление и активные действия националистических движений в советских республиках. СМИ тоже перестали поддерживать существующий строй, появились антисоветские издания.

В период перестройки средства массовой информа- 
ции претерпевали изменения под влиянием исторических событий, но и ускоряли такие изменения. Следует отметить, что СМИ способствовали переходу от тоталитарной системы к демократической. Для СМИ период перестройки ознаменован тем, что государство и общество начали изменять общественный и политический строй, изменился уровень гласности, возникли новые общественный организации и движения, которые могли открыто выражать своё мнение, даже если таковое являлось оппозиционным. Соответственно представители таких движений составляли собственную альтернативную прессу. В этот исторический период было опубликовано много работ, которые старались осветить исторические события, которые предшествовали периоду перестройки.

СМИ были вовлечены в противоборство различных общественных интересов. Они одновременно являлись барометром перемен, площадкой для социальных столкновений. Деятельность СМИ инициировала дискуссии по наиболее актуальным вопросам. Благодаря активности СМИ стала заметной разница в политических интересах общества, обострились конфликты между акторами политических событий. За годы перестройки под воздействием перемен изменилось само содержание медиаинформации [1, С. 7]. Например, увеличилось многообразие аудиторных интересов.

Донбасс во время перестройки долгое время не испытывал дефицита товаров и продуктов. Однако тяжелая экономическая ситуация в итоге коснулась и Донецкой области. Обстановка осложнилась тем, что трудовые конфликты на угольных шахтах и предприятиях в 1989 г. переросли во всеобщую забастовку. Шахтеры требовали повышения зарплат и улучшения условий труда и быта. Забастовка 1989 года распространилась по всему Донбассу. Подавляющее большинство шахт не работали (110 из 121). В результате рабочим удалось добиться обещаний со стороны власти выполнить их требования. Для контроля за выполнением данных обещаний правительства шахтерами были созданы спецаиальные органы самоуправления - комитеты по стачкам (или стачкомы). Тем не менее, фактически рабочие не добились нужных результатов - их требования не были выполнены со стороны власти.

Ситуация в регионе обострялась с каждым днем. Экономический кризис повлек исчезновение из магазинов самых необходимых товаров. Данное обстоятельство усугубляло ситуацию. Дефицит продуктов стал причиной появления многочисленных очередей. Именно поэтому в 1991 г. бастующее движение, которое выдвигало требования только экономического характера, стало приобретать политические формы. Шахтеры уже требовали отставки М. С. Горбачева, который в то время имел должность президента Советского Союза. В регионе ста- ли популярны антикоммунистические лозунги. Таким образом, затянувшаяся стачка на Донбассе стала одной из основных причин ликвидации коммунистической партии и распада СССР.

Как уже быдл отмечено, реформы, которые начали вводится в апреле 1985 года, должны были изменить общественно-политическую, экономическую, социальную и идеологическую сферы жизни СССР. Политика гласности должна была сделать советское общество более открытым, должна быть ликвидирована цензура. Политическая жизнь Донбасса, как, впрочем, и всего Советского Союза формировалась из событий, которые не были характерны для советского общества. Уже упомянутые события находили отображение в прессе: шахтерские забастовки, расслоение общества, критика КПСС и антикоммунистические лозунги. Стоит отметить, что изначально гласность понималась, как более широкое информирование общества о новом политическом курсе партии. В то же время пресса должна была писать об изменениях в обществе. Тем не менее, цензура, пусть и не такая строгая, существовала для СМИ. Государство требовало, чтобы информация подавалась в нужном контексте, СМИ оставалось идеологическим инструментом партии. Так оружием пропаганды оставались такие издания как «Социалистический Донбасс», «Комсомолец Донбасса», «Донбасс», «Сільский Донбасс», «Вечерний Донбасс». Однако с середины 1986 года изменяется риторика в печати, это изменение происходит в связи с переменами в понятии и сущности гласности.

Гласность становится начальной вехой демократизации общества. Важно отметить, что с демократизацией центральных и региональных СМИ была неоднозначная ситуация: с одной стороны, деятельность прессы должна была стать более свободной, но с другой стороны сохранялась цензура и давление со стороны коммунистической партии. В этом и заключалась основная трудность в становлении новой демократической региональной прессы. В связи с этим сложилась ситуация, что пресса транслировала обществу правильность выбранного курса партии. Однако ослабление в цензуре способствовало появлению публикаций критического характера, при этом степень критики возрастала [2, С. 238].

В печати стали чаще появляться материалы, критикующие существующий общественно-экономический строй. СМИ стали затрагивать проблемы «белых пятен в истории». Соблюдались условия существующей «субординации», то есть региональные СМИ ориентировались на центральные общесоюзные издания, такие как «Огонек», «Правда», «Известия». Однако гласность не была тождественна свободе слова и власть всячески старалась контролировать деятельность СМИ. Но цензура тоже претерпела изменения: наказания за инакомыслия стали не такими суровыми. Иными словами, началось 
развитие альтернативных печатных изданий. Сначала ее тиражи были небольшими. Кроме того, такие издания находились на полулегальном положении. Однако именно они в острой и резкой форме описывали общественные проблемы.

Постепенно периодические издания Донбасса стали выходить из-под контроля цензуры. Новые печатные издания формировались на уровне самиздата, они начали высказывать независимую точку зрения. Так, в структуре новой прессы формировались издания, которые уже были вне контроля органов власти. В качестве яркого примера такого издания, можно отметить некоммунистическую газету Донецка «Город», которая была создана в 1990 году. Все эти процессы происходили на фоне общей дестабилизации социально-политической ситуации в стране. Возросла конфронтация КПСС и новыми общественными объединениями, которые сформировались в период демократизации и были разочарованы проводимыми реформами. Изменения коснулись и отечественной прессы. В Советском Союзе был принят закон «О печати и других СМИ» от 12 июля 1990 года, который наделил печатные СМИ широкими полномочиями.

Количество региональных газет резко возросло, изменилась их политическая позиция в отношении оценки существующих социально-экономических проблем. Несмотря на то, что большинство газет и журналов все еще находятся под контролем правящей партии, они все равно стали пропагандировать демократические взгляды. В рамках процесса трансформации региональных печатных СМИ Донбасса в период перестройки (19851991) можно обозначить несколько этапов:

1. Пресса все еще остается интерпретатором коммунистической системы, для нее действуют жесткая цензура и запреты. Она информирует общество о том, что выбранный курс партии единственный и правильный

2. Гласность и политика демократизации общества приводит к ослаблению цензуры. Гласность становится основой нового советского общества данное обстоятельство дает возможность прессе открыто освещать изменения на Донбассе и в стране в целом.

3. Все эти изменения в советском обществе привели к появлению альтернативных печатных изданий, а также были полностью ликвидированы запреты и ограничения в оценке событий. Этот этап ознаменовал начало новой свободной прессы на Донбассе.

4. Наконец итоговым этапом является создание независимой прессы и появление новых печатных изданий в регионе. Мнение и специфика интересов Донецкого края постепенно сформировалась в СМИ под влиянием региональных и общегосударственных социально-политических процессов.
Таким образом, были рассмотрены основные этапы эволюции региональных СМИ Донбасса. Важно отметить, что Донбасс долгое время оставался благополучным регионом несмотря на общую тяжелую экономическую ситуацию в стране. Альтернативная пресса в данном случае стала катализатором растущего недовольства шахтеров и всего населения региона. Альтернативными изданиями Донбасса периода перестройки стали такие газеты и журналы, как «Город», «Салон Дона и Баса», «Вестник ЛПУ», «Гражданский конгресс». Многие из них возникли на почве существовавших раньше советских газет.

Как уже было отмечено, изначально печатные СМИ Донбасса подчинялись требованиям существующей идеологии. Они должны были правильно доносить информацию до читательской аудитории. Так, газета «Социалистический Донбасс» печатала статьи, в которых поддерживала процесс перестройки и в целом пропагандировала политику Горбачева. Так публиковались сюжеты, связанные с положительным влиянием реформ на политическую жизнь страны, печатались выступления и публичные обращения первого президента СССР. Для того периода времени были характерны идея возврата к Ленину и Октябрьской революции 1917 г. Примерно 60 статей на эту тему вышли в печать в 1987 году [3, С. 154].

В скором времени ситуация меняются: в газетах появляются альтернативные статьи. Например, в статье «Очищение. Откровенный разговор» проводится анализ писем от читателей, которые пришли в редакции. В этих письма большая доля негатива по отношению коррупции со стороны чиновнического аппарата. В 1988 году меняется тематика исторических статей в прессе Донбасса, в этом же году их становится очень много. 1989 год ознаменовал себя тем, что социально-экономическая и политическая проблематика выходит на передний план в СМИ Донбасса.

Широкое освещение в прессе Донбасса получили забастовки шахтеров и закон, связанный с ограничением продаж алкоголя. Публиковались требования рабочих по отношению к власти, пропагандировались лозунги за здоровый образ жизни. Большинство СМИ следовали установленным властью правилам и цензуре. Ситуация изменилась в 1991 году, тогда все донецкие СМИ взяли на вооружение принцип открытости и гласности. В газетах публиковалось мнение редакции о том, что газета - это не место для заявлений резолюций и обращений. Было отмечено, если какая-либо партия хочет опубликовать что-то в газете, то должна оплатить данную публикацию.

Таким образом, СМИ Донбасса выразили свою позицию по поводу проводимых реформ и экономических обвалов перестройки. Регулярно публиковались сюжеты по митингам и забастовкам. Кроме того, в печатных 
материалах уже прослеживались протестные настроения по отношению к существующему режиму. Пресса также перестала быть скованной правилами цензуры. Государство принципом открытости и гласности обратило против себя СМИ.

Донбасс даже во времена перестройки долгое время был экономически благополучным регионом. Однако с конца 80-х годов социально-экономические проблемы и нестабильная политическая ситуация затронули и его. Эти обстоятельства способствовали возникновению альтернативных печатных изданий, благодаря публикационной активности которых крепли антикоммунистические и националистические движения. С другой стороны, после распада СССР в СМИ Донбасса стала прослеживать тенденция к сближению с Россией.

\section{ЛИТЕРАТУРА}

1. Соколова Т.Л. Понятия «перестройка», «демократизация», «гласность» в материалах региональной печати 1985- 1991 гг. // Вопросы территориального развития. 2015. № 5 (25). С. 1-14.

2. К Коэн С. Можно ли было реформировать советскую систему? // Прорыв к свободе: 0 перестройке двадцать лет спустя (критический анализ). - М.: Алпина Бизнес Бук, 2005. - 436 с.

3. Боффа Дж. История Советского Союза. - М., 1994. - Т. 1.520 с.

4. Согрин В.В. Политическая история современной России. 1985-2001: от Горбачева до Путина. М., 2001. 272 с.

\section{(с) Поклонский Александр Олегович (aleksandrpoklonskij4@gmail.com). \\ Журнал «Современная наука: актуальные проблемы теории и практики»}

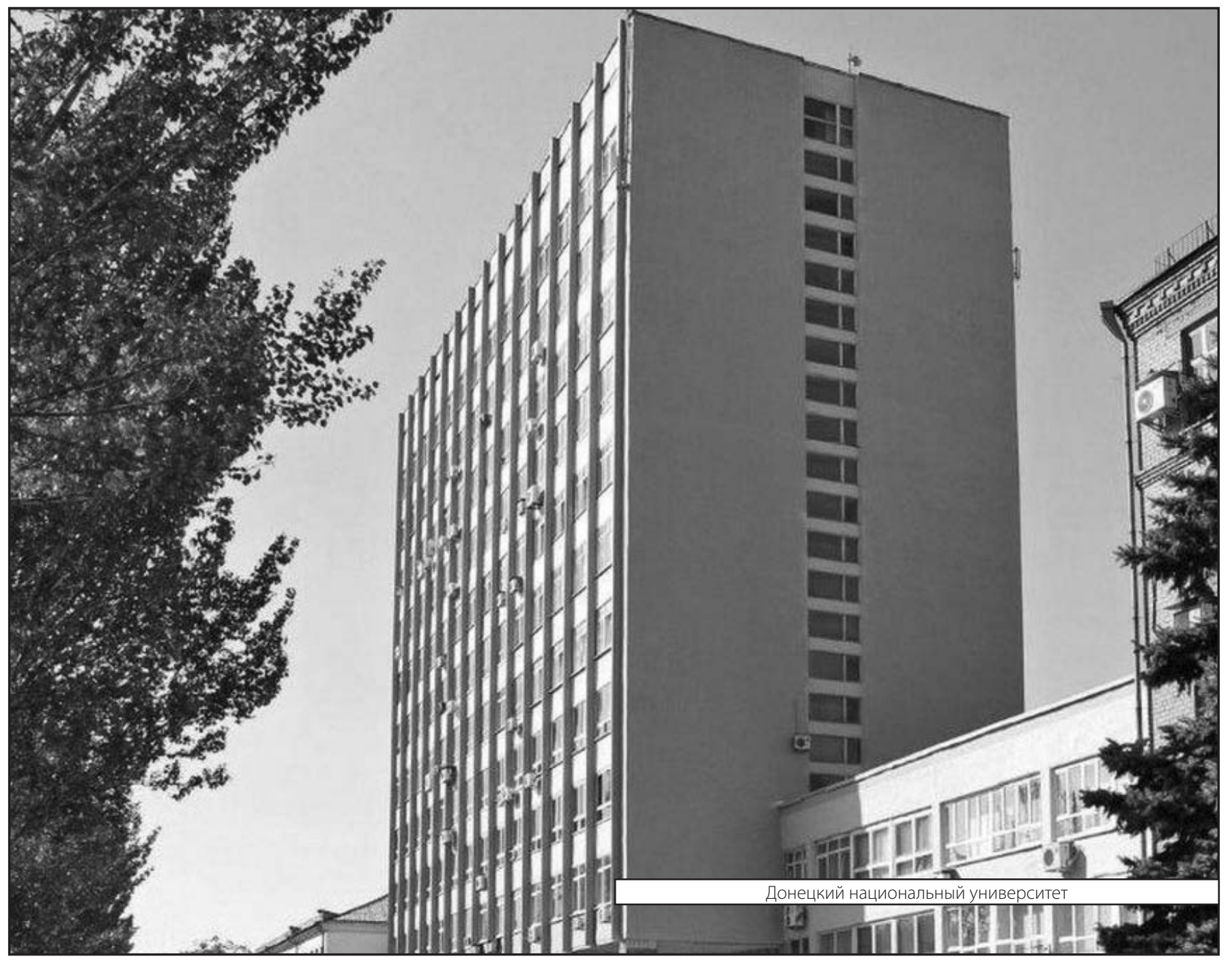

